\title{
Cramping Pain
}

National Cancer Institute

\section{Source}

National Cancer Institute. Cramping Pain. NCI Thesaurus. Code C101173.

A sense of discomfort or distress that is spasmodic or clenching. 